\title{
Challenges and Coping Strategies of Married Women in Post Disaster Situation: A Study on Khulna District
}

\author{
Mithun Mondal ${ }^{1}$, Md Abdur Rashid ${ }^{2,}$,, Shimon Rahman ${ }^{1}$, Md. Noman Amin ${ }^{1}$ \\ ${ }^{1}$ Department of Sociology, Bangabandhu Sheikh Mujibur Rahman Science and Technology University, Gopalganj, Bangladesh \\ ${ }^{2}$ Department of Sociology, Hajee Mohammad Danesh Science and Technology University, Dinajpur, Bangladesh
}

\section{Email address:}

mithunbsmrstu@gmail.com (M. Mondal), rashidm@unbc.ca (Md A. Rashid), shimonrahman16@gmail.com (S. Rahman), mdnomanamin $a$ gmail.com (Md. N. Amin)

${ }^{*}$ Corresponding author

\section{To cite this article:}

Mithun Mondal, Md Abdur Rashid, Shimon Rahman, Md. Noman Amin. Challenges and Coping Strategies of Married Women in Post Disaster Situation: A Study on Khulna District. Advances in Sciences and Humanities. Vol. 4, No. 3, 2018, pp. 37-44.

doi: $10.11648 /$ j.ash.20180403.11

Received: July 30, 2018; Accepted: August 20, 2018; Published: September 5, 2018

\begin{abstract}
Bangladesh is a disaster-prone country mainly due to its geographic location. Disasters such as floods, river bank erosion, cyclone, tornado, waterlogging, salinity intrusion etc. are gradually intensifying and composing risks for the coastal people especially women in Bangladesh. The aim of this research is to explore the challenges and coping strategies of married women in post disaster situation. Women are in weaker position within the existing gender relationship. This type of gender relationship makes women more vulnerable in post disaster situation. They became more vulnerable in post disaster time because they have to play significant role to protect family and all other things. The field of research was Dacope upazila (Gunari) in the district of Khulna. This study followed mix methodology where questionnaire survey is used for quantitative data and in-dept interview is used for qualitative data. 125 married women (20-60 aged) were selected for surveying and five respondents were selected for in-dept interviewing. The study findings demonstrated that women suffer from many harmful conditions and victim of discrimination by others. They do not get proper treatment and opportunities in disaster situation. They usually try to cope with disasters with their traditional knowledge and arts. Exploring these realities this study suggests that emergency relief facilities, providing necessary support regarding primary and secondary impacts and so on should be in action to reduce vulnerable position of women in disaster prone areas.
\end{abstract}

Keywords: Disaster, Married Women, Coping Strategies, Post-Disaster

\section{Introduction}

Natural disaster is a common annual incident in Bangladesh [1-2]. The country is worst victim of different kinds of disasters like flood, tropical cyclones, tornados, tidal surges, drought and large-scale river erosion etc. These natural calamities cost several lives and properties of the country [3]. Global warming and climate change pulled Bangladesh on the verge of natural calamities prone areas. Specially most of the southern districts of it are at the risk of natural disasters and meteorological disturbances [4]. The coastal region of the country is mostly vulnerable of devastating tropical cyclones that originate in the Bay of Bengal, water contamination, ecosystem destruction caused by rising sea levels and so on [5-
6]. Recently it has witnessed two consecutive cyclones named SIDR in 2007 and AILA in 2009. Paul (2009) found that cyclone SIDR that hit the country on 15th of November 2007 caused about 3,406 deaths and over 55,000 people were victim of physical injuries [7].

In Bangladesh women possess more vulnerable position than male during these disasters due to poverty, social practices, norms, and their marginal position in the social system [8]. Gender biased policies, institutional frameworks and adaptation measures are also responsible for placing women in vulnerable positions. Men usually control the power of income and property distribution, access to credit, decision-making processes, and so forth. Women have limited access and power to practice over these. Even they have no rights to access information [9]. Many women are 
not allowed to leave their homes without the permission and accompany of male members [10].

In Bangladesh, women face several problems to manage their risks during all type of disasters. Women experience various types of physical, sexual, emotional and domestic violence that specially increase during and after a disaster [4]. Due to lack of access to information in emergency condition and lack of decision making power during disaster prevention and mitigation programs women became most vulnerable group than any other segments of a society. Sometimes they are also excluded from disaster recovery mechanism and planning at the national level [11].

In Khulna region, there exist a lot of problems in disaster management programs, disaster and preparedness programs, and other disaster mitigation programs. Women in these regions remain more vulnerable than in any other region of Bangladesh. They often don't get proper support from the government and non-governmental organizations. Traditionally they adhere to indigenous mechanism as a coping strategy. Though these are not properly fitted to them, but is appreciable [9]. However, based on these existing realities the present study initiated to assess the challenges and coping strategies of married women in post disaster situation. It also aims to discover how women face and perceive disaster within the existing strategies and gender relationship.

\section{Conceptual and Contextual Framework}

Disaster is the most natural harmful condition for all people but especially extra pressure for women. During disaster women have to play vital roles. Social roles that are assigned from traditional values limit their opportunities to play dominant role in different position. Most of the time they have no rights or limited rights regarding access to markets, education, health services and government-oriented jobs. In patriarchal system men reserve family planning power. When men continuously tend to extend family size, it affects women's health as taking too many children is a challenging issue for women health [9].

Women remain vulnerable to sexual and reproductive health problems. Recent disasters such as Asian tsunami, Hurricane Katrina and the earthquake of 2005 in Kashmir witnessed sexual violence against women including public sexual harassment, domestic abuse, eve-teasing and so on that kept them frightened. In such situation, women feel fear and insecure in participating post disaster recovery and aid programs e.g., relief programs, disaster mitigation programs etc. [12]. Refugee or shelter camps very often expose women to various types of violence. Shelter camps are usually constructed without considering gender issues. Women in these centers feel insecure and frightened. They need extra privacy within their special situations but these facilities are totally absent in these centers. [13]. Sometimes women deny to take shelter in these camps and unfortunately sometimes they suffer from forced abortion [14]. As they are marginal group, fail to access information and lack the controlling rights, they can't mitigate or minimize their risks [1].

Enarson (2006) mentioned that women have no decisionmaking power in patriarchal practice-based Bangladesh society. It is due to absence of huge personal assets [15]. They are restricted in accessing resources i.e., social networks, transportation, information, control over land and other economic resources. These are essential for disaster preparedness, mitigation and rehabilitation [13]. Enarson described:

... First, women become economically insecure after a disaster. Second, women's responsibility and workload increase. Third, women's working conditions deteriorate. Fourth, women take considerably more time to compensate for the economic losses caused by the disaster compare to that of men [15].

Household chores, intra household food distribution etc. largely affect their academic life [1]. "Women and adolescent girls are usually responsible to fetch drinking water from distant sources, even 5 to 6 kilometers each day in some southern areas". Irrespective of the distance between the source and their dwellings, even during their pregnancy, women are forced to fetch water. In exchange of participating such activities they have to cost their education life [16]. Women often face several gynecological problems in the long run for handling extra duties during post disaster period [17]. In absence of freshwater, girls cannot maintain suitable reproductive health condition and often suffer from several perineal rashes and urinary tract infections [18].

Women actively involved in disaster prevention or mitigation mechanism that improve effectiveness of such programs [19]. Women can effectively participate with such program as they have vast experiences about their household and their surroundings. They can also contribute to the process of assessing vulnerabilities and opportunities. Specially regarding the child, adolescence and elderly care women play outstanding roles $[1,11]$.

As flood minimize land-based employment opportunities, the male member of these region usually migrates to a high employment facilitated areas. As a result, women headed household in flood affected areas are increasing. Sometimes these male members never return to their home or family. "In coastal areas, women control homestead-based livelihoods, livestock, fisheries, trees, seeds and animal fodder. Despite the limited resources in coastal areas women play a significant role in food preservation to combat the adverse situation" [1]. Women in coastal areas mostly try to cope with disasters with their traditional knowledge and mechanism [20].

\section{Methodology}

This study covered the area of Sutarkhali union at Dacope upazila which is situated in the district of Khulna. We selected our field for conducting the research beyond the influence of funding, personal interests and emphasized the societal needs, as the findings of the study could be more applicable to societal benefit. The area of Dacope Upazila is 
991.57 sq. $\mathrm{km}$. consisting nine unions. The total populations were 157489 where males were 83193, females were 74296 in 2011. The Sutarkhali union consists four villages and total populations were 8529 (male 4403 and female 4126) in 2011 [21]. We used questionnaire survey for quantitative data and in-dept interview for qualitative data [22]. We employed qualitative methods in an attempt to draw out multiple meanings and explanations from the participants through their individual experiences rather than a single and objective explanation. With a view to choose a representative sample, purposive sampling method is applied for this research. By using this sampling method data has been collected from 125 respondents from the married women in this area who are victimized by at least one natural calamities. For collecting the necessary information, a pretested semi-structured questionnaire with a series of close and open-ended questions has been used. For analyzing quantitative data popular SPSS software has been used. Qualitative data has been firstly translated from Bangla to English and then generalized for presentation. Both data presented one after another so as both can supplement each other.

Characteristics of the Sample

Table 1. Age structure of the respondents.

\begin{tabular}{lll}
\hline Age group & Frequency & Percentage \\
\hline $20-30$ & 13 & 10.4 \\
$30-40$ & 35 & 28 \\
$40-50$ & 65 & 52 \\
$50-60$ & 12 & 9.6 \\
Total & 125 & 100 \\
\hline
\end{tabular}

In this study the age composition of the respondents constituted as $10.4 \%$ from $20-30,28 \%$ from $30-40,52 \%$ from $40-50$, and $9.6 \%$ from 50-60 age groups.

Table 2. Religious attachment of the respondents.

\begin{tabular}{lll}
\hline Religion & Frequency & Percentage \\
\hline Islam & 68 & 54.4 \\
Hinduism & 57 & 45.6 \\
Total & 125 & 100 \\
\hline
\end{tabular}

Table 2 represents the religious profile of the respondents. It shows that 54.4 percent are Muslim and 45.6 percent are Hindus.

Table 3. Disaster faced by the respondents.

\begin{tabular}{lll}
\hline Types of Disaster & Frequency & Percentage \\
\hline Flood & 107 & 85.6 \\
River erosion & 73 & 58.4 \\
Excessive rainfall & 15 & 12 \\
Cyclone \& other & 5 & 4 \\
\hline
\end{tabular}

$[\mathrm{N}=125$, More than one answer is accepted $]$

Table 3 represents information about disaster faced by the respondents. We see that most of the respondents $(85.6 \%)$ suffered from flood while 58.4 percent respondent faced river erosion, 12 percent respondents faced excessive rainfall and 4 percent respondents suffered from cyclone \& other disasters.

\section{Results}

The following figure represents information about getting warning signal of disaster. We see that, most of the respondents $(62.5 \%)$ do not get warning signal in disaster situation where 37.5 percent respondents get warning signal. It is the most important issue for married women. If they get warning signal, they will save their valuable things. Most of the married women do not get warning signal of disasters due to lack of modern weather forecasting technology like radio, TV and so on.

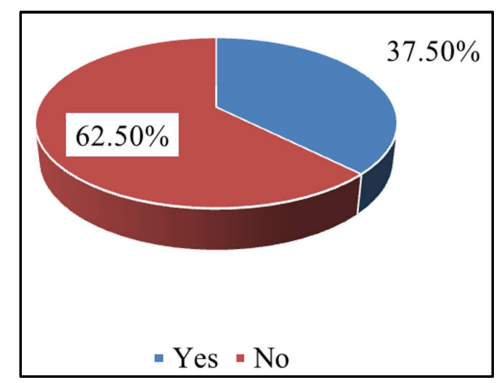

Figure 1. Information about getting warning signal of disaster.

Islam (2012) stated that, "Most of the inhabitants of this areas depend on the indigenous technology for getting the signal of disaster. Cloud cover, wind direction and speed, fog, water color and temperature, rising water level bear the signs of flood, rainfall and drought. Movement and behavior of insects and animals bear the signal of the disaster, as ants with eggs in the mouth start climbing up for shelter before flood; grasshoppers fly unitedly before heavy rain and storm; if dog cries in pathetic voice flood will come and/or food crisis will prevail; if fox calls in day time, crow calls at night flood or a storm will soon take place" [1]. In an individual question, a woman stated that:

"...faced most of the major disaster near present. When people noticed about the disaster we didn't even believe it. When it came, it was so late and ultimately it hit us seriously. Our house was surrounded by several big trees. When storm and wind take in place, it caused of ruining our houses. All of our livestock ruined. Our cultivatable land went under water. All sources of money making became ruined. Thus, we became homeless, foodless" (Pritilota Rani, age 40).

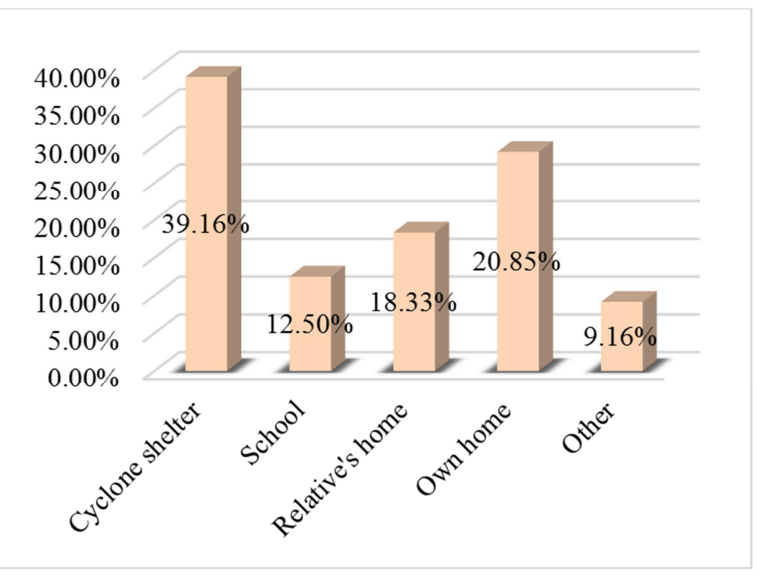

Figure 2. Information about the shelter place of the respondents. 
The above figure shows that 39.89 percent take shelter in the cyclone shelter, 12.5 percent take shelter in the school, 20.85 percent stay in own home and 18.33 percent respondent go to relatives' home. Sheltering place is a most important matter for married women because they cannot move freely and share personal activities.

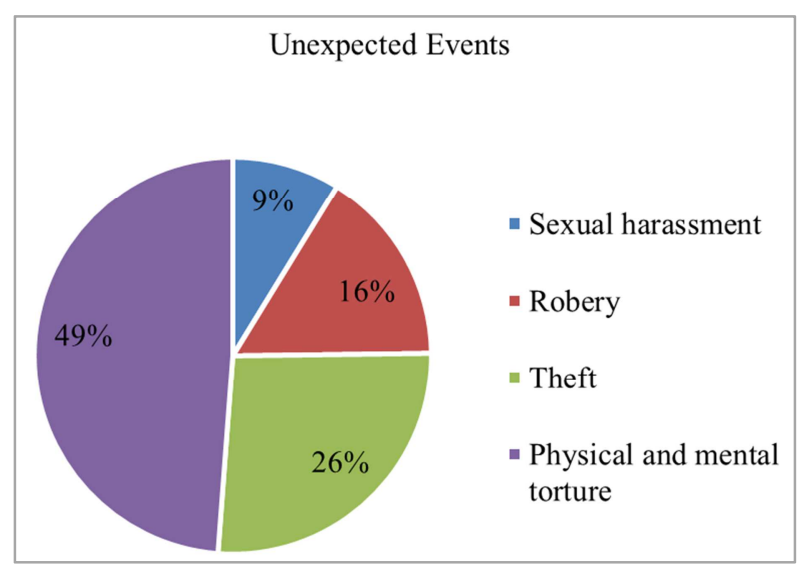

Figure 3. Unexpected events faced by the respondents in post disaster situation.

From the above figure, it is observed that most of the respondents face several type of unexpected events at the time of disaster and post disaster situation. It is found that 49 percent respondents faced physical and mental torture and $9 \%$ faced sexual harassment. Women also suffered by theft $(26 \%)$ and robbery $(16 \%)$. All these factors create psychosocial impact on married women's life. "We (married women) specially getting violated during post disaster situation" (Esita Roy, aged 27).

Table 4. Status and Types of food stored for emergency.

\begin{tabular}{cll}
\hline & Frequency & Percentage \\
\hline Food stored & & \\
Yes & 37 & 29.6 \\
No & 88 & 70.4 \\
Total & 125 & 100 \\
\hline
\end{tabular}

Table 4. (cont.)

\begin{tabular}{lll}
\hline Types of food & Frequency & Percentage \\
Dry food & 15 & 40.54 \\
Food need to process & 20 & 54.05 \\
Other & 2 & 1.6 \\
Total & 37 & \\
\hline
\end{tabular}

This study shows that most of the respondents' families cannot store food for competing disaster due to their poverty. Only 29.6 percent can store different kinds of food before disaster. In most cases, many of them fail to bring these at the shelter places. 40.54 percent respondents can store dry food like 'chira', 'muri', 'gur' and so on while 54.05 percent respondents noticed that stored foods need to be cooked which is not possible owing to the lack of fuel or other cooking facilities. Most of the respondents told that they lacked sufficient food and relief in sheltering places.
Table 5. Capacities of buying food and medicine after disaster.

\begin{tabular}{lll}
\hline Capacities & Frequency & Percentage \\
\hline Sufficient capacity & 14 & 11.2 \\
Insufficient capacity & 44 & 35.2 \\
No capacity & 67 & 53.6 \\
Total & 125 & 100 \\
\hline
\end{tabular}

Above table shows that most of the respondents (53.6\%) have no capacities for buying food and medicine. It also shows that 35.2 percent pertain insufficient capacities and only 11.2 percent have the capacity to buy food and medicine after disaster. They became vulnerable due to loss of their food, assets, livestock, agricultural production and loss of job. "All the cultivation compatible land gone under water. The main source of our yearly livelihood thus ruined, we became vulnerable and remain on the verge of extinction. Even after we had no capacities to buy and store foods for basic livelihood" (Khadija Begum, aged 33).

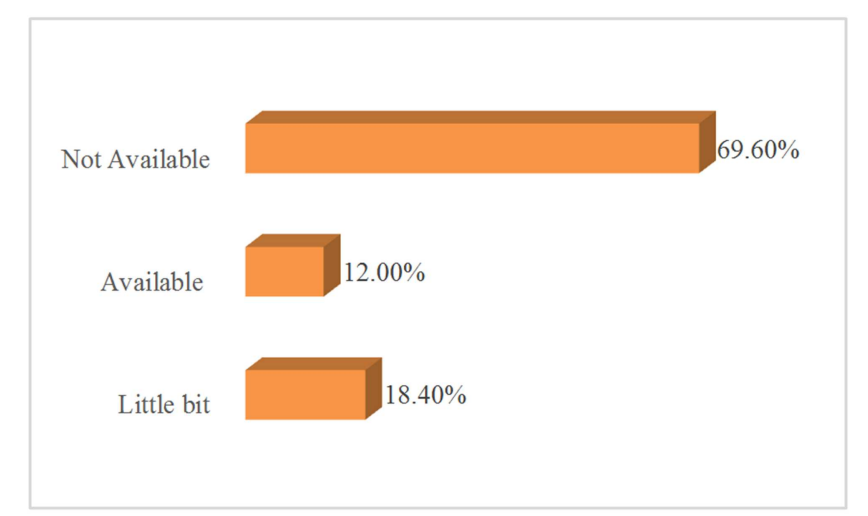

Figure 4. Information about the availability of drinking water after disaster.

18.4 percent respondents opined that they could avail pure drinking water while 69.6 percent opined that they couldn't avail pure drinking water after disaster. There is a significant correlation between the availability of pure drinking water and the types of diseases suffered by the respondents after disaster. This study explores that almost all of the respondents are attacked by various diseases after disaster. Lack of medical facilities, malnutrition, lack of uncontaminated drinking water and lack of proper sanitation facilities are the common scenario during disaster.

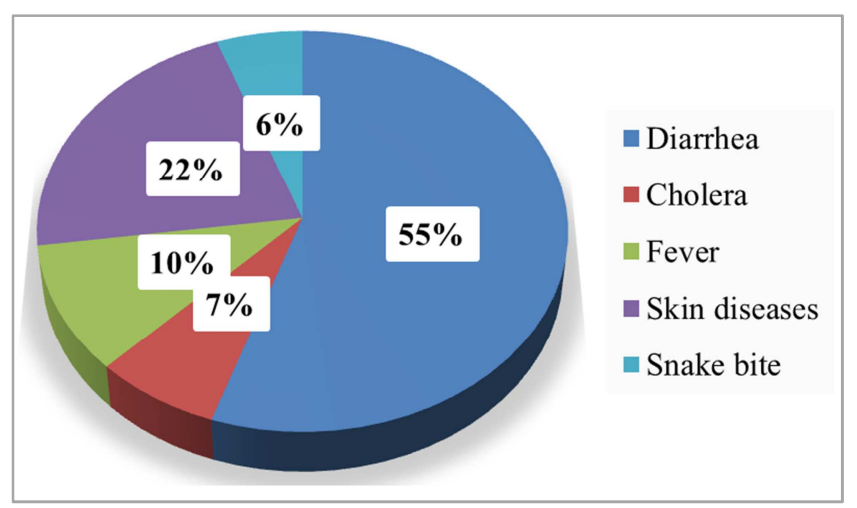

Figure 5. Types of diseases suffered by the respondents after disaster. 
It is observed that 55 percent respondents suffered from diarrhea, 6 percent from snake bite, and 7 percent from cholera, 10 percent from fever and 22 percent from skin diseases. Most of the respondents suffered from water borne diseases after a disaster. Actually, married women face huge challenges in post disaster time because they have to take care of all family member. Elder person totally depends on the family member specially on women. During this situation if they attacked by any diseases, it creates a sort of risk and harmful situation for them.

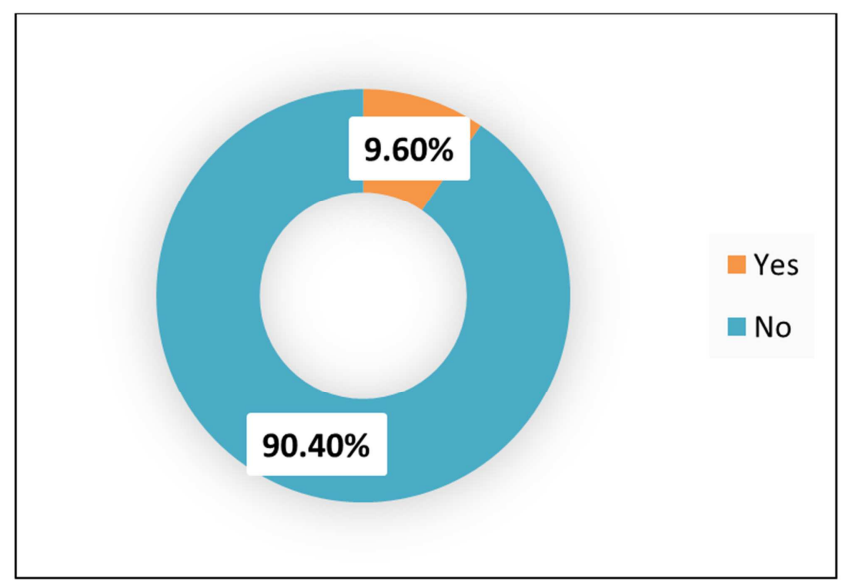

Figure 6. Information about the use of healthy sanitary latrine by the respondents.

Table 6. Information about medical treatment getting by the respondents in post-disaster situation.

\begin{tabular}{lll}
\hline & Frequency & Percentage \\
\hline Got medical treatment & & \\
Yes & 17 & 13.6 \\
No & 108 & 86.6 \\
Total & 125 & 100 \\
\hline
\end{tabular}

This study shows that most of the respondents $(86.6 \%)$ didn't get proper medical treatment. Only 13.6 percent respondents get facilities of proper medical treatment. It is the most challenging issue for married women. If they cannot get proper medical treatment, they will suffer from many problems. Pregnant married women, lactating mothers and differently disabled married women are mostly being suffered, as it is difficult to move for them. Sometimes married women cannot express their problems.

A respondent opined that:

"I was pregnant in a disaster time. I along with my family got migrated to cyclone shelter but it is not suitable place for pregnant women. Though family members helped me a lot but due to absence of special facilities, I suffered a lot. Medical facilities and extra care that is specially needed for a pregnant woman were not available at cyclone shelter center. Where there is a question of living is there any sort of extra care?" (Basonti Rani, aged 32).

Use of healthy sanitary latrine is an important requisite for maintaining good health. This study shows that only 9.6 percent respondents have the opportunity to use healthy sanitary latrine. More than 90 percent respondents do not get any opportunities to use healthy sanitary latrine. There are no separate latrine facilities for married women at the shelter places.

Table 7. Activities of the respondents before disaster.

\begin{tabular}{lll}
\hline & Frequency & Percentage \\
\hline Before disaster (work) & & \\
Outdoor work & 49 & 39.2 \\
Household work & 76 & 60.8 \\
Total & 125 & 100 \\
Outdoor work (N=49) & & \\
$\quad$ Day labor & 20 & 16 \\
$\quad$ Maid servant & 7 & 5.6 \\
$\quad$ Agricultural work & 12 & 9.6 \\
$\quad$ Others & 10 & 8 \\
$\quad$ Total & 49 & \\
\hline
\end{tabular}

Married women and adolescent girls suffer mostly as sanitation systems destroyed. Many of them reported that they refrain from using toilet for a day long and consequently suffer from urinary tract infections. "When I was in a cyclone shelter usually I felt shyness when I need to use of sanitation as it was in public place" (Rupa Rani, age 25). In this study we found that 39.2 percent respondents are engaged in various types of work (day labor $16 \%$, maid servant $5.6 \%$, agricultural work $9.6 \%$ and other $8 \%$ ) including household activities.

Table 8. Activities of the respondents after disaster.

\begin{tabular}{lll}
\hline After disaster (work) & Frequency & Percentage \\
\hline Outdoor work & 9 & 7.2 \\
Household work & 71 & 56.8 \\
Loss of work & 45 & 36 \\
Total & 125 & 100 \\
\hline
\end{tabular}

After a disaster significant number of the respondents (36\%) lost their job who previously engaged as day laborer, maid servant, agricultural and other activities. Besides, respondents stated that they lost their outdoor activities after disaster. This study shows that most of the disaster affected married women cannot join their workplace after disaster and therefore cannot earn which create the situation more vulnerable for them and their family. Only 7.2 percent respondents can continue household and various types of work.

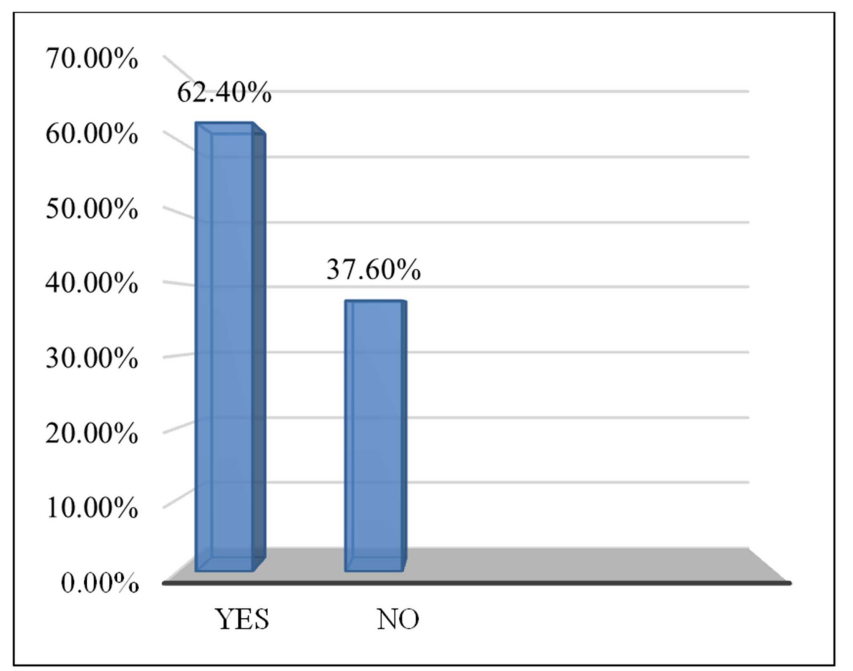

Figure 7. Getting financial support. 
The figure shows that 62.4 percent respondents get financial support by others. If women get financial support, they could cope easily and maintain their family. But we see that 37.6 percent respondent could not get financial support by others.

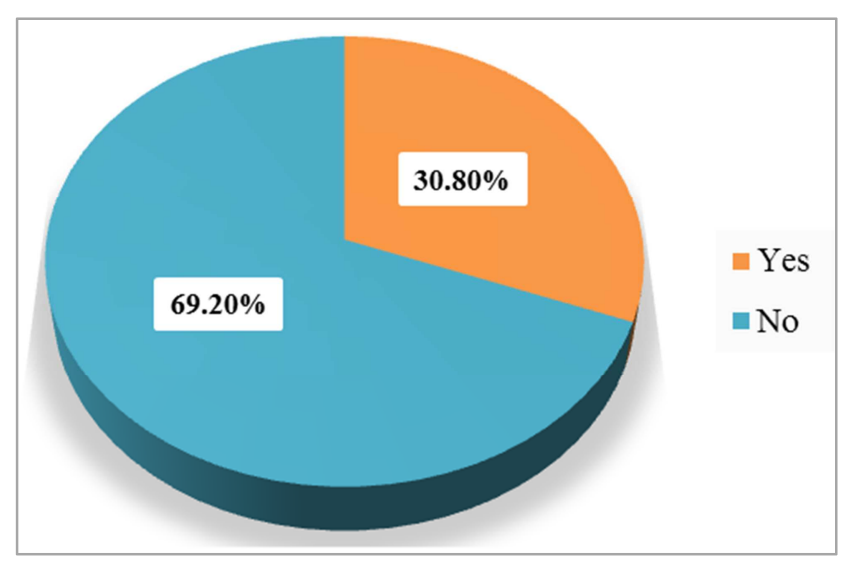

Figure 8. Getting loan by the bank and others.

The present study shows that 30.8 percent respondents got loan by the bank and other organization. But most of the respondents opined that only powerful person and active political personnel get loan in post disaster situation. A huge number of the respondents $(69.20 \%)$ did not get loan.

Table 9. Facing discrimination during relief distribution.

\begin{tabular}{lll}
\hline Discriminated & Frequency & Percentage \\
\hline Yes & 79 & 63.2 \\
No & 46 & 36.8 \\
Total & 125 & 100 \\
\hline
\end{tabular}

The table shows that 63.2 percent respondents faced discrimination by their fellowmen. Food security must be needed for any family during post disaster period. In a question, the present study found that 36.8 percent of the total respondents easily get relief in post disaster situation. Actually, the relief is distributed by the political parties and powerful people. Most of the respondents think that when a person builds up good communication and relation with such political personnel, actually they have the greater chance to get such facilities in every time. Many people strongly support that many NGOs help them financially, but government relief is not distributed equally. In a personal question a respondent stated that:

"my husband works abroad. When the cyclone SIDR attacked, I was alone with my two little sons. When thunder storm and wind began to blow I became worried about what should to do. The surrounding worst situation will remain evergreen in my mind. Disaster devasted all of our livelihood requisites so that we were bound to take relief provided by the government and NGOs. But having absence of male member I got a little bit preference in getting relief distribution" (Rupa Rani, aged 25).

The overall scenario indicate that married women face many challenges and their coping strategies are also vulnerable.

\section{Discussion}

This study is conducted among the married women to assess vulnerable positions and challenging issues that they face after a disaster. The study area was selected in a southern part of Bangladesh that usually covered with disaster in almost every year. Married women between the age of 20-60 were the respondents of this study. Among the total 125 respondents, most of them faced any type disaster that usually occurred in these regions. Among the types include flood, river bank erosion, draught, excessive rainfall, cyclone and so on. This study shows that most of the respondents $(62.5 \%)$ get noticed before disaster occurrence. In the disaster-prone areas, residents are being transferred to a near safe place to avoid life causes. This study shows that after being noticed about upcoming disaster most of the residents are moved to a near safe shelter center. Shelter center includes government sponsored cyclone center, relatives' home, school and so other places.

During disaster, married women are mainly vulnerable of facing unexpected events. Physical and mental torture, sexual harassment, robbery, theft and so on are common in the disaster-prone areas. In this study we found a large number of distributions $(48.80 \%)$ who faced any type of physical and mental torture in post disaster situation. Married women specially who are being separated from their husband, whose husband work abroad or widowed are more vulnerable of it. As disaster devasted shelter, cropping land and all the surrounding environment, a level of food scarcity originates during that time. This study shows that some of them store foods for post disaster situation but due to poverty most of them have no abilities of storing foods. About $70 \%$ of the respondents affirmed that they have no such abilities to store foods for post disaster condition. Food scarcity and lack of and pure drinking water adds extra burden for the people specially for married women.

A particular type of diseases spread after disaster period including diarrhea, cholera, fever and so on. As disaster creates question of their livelihood, they lacked of necessary medical facilities needed specially for disaster situation. Most of the respondents (more than 53\%) opined that they have no sufficient ability to buy medicine to compete with such type of diseases. Besides lack of sufficient and nutritious foods, pure drinking water create several types of diseases during this period. In this study $69.60 \%$ of the total 125 respondents opined that pure drinking water is totally unavailable during post disaster condition.

Absence of medical care facilities in these areas also add problems for married women. Usually affected people are being transferred to a near safe place i.e., shelter centers. These shelter centers are often not women friendly. Pregnant women need extra care but it is absent in shelter center. In cyclone shelter center married women face different problem that they cannot express to their fellowmen. Cyclone center are mainly designed for both male and female where married women lacked privacy that is needed for them.

As disaster alters the usual environment, it causes for 
changing people's working field. Most of them became unemployed due to devastating their workplace. Women who were engaged with any type of economic activities before disaster sometimes lost their job. In this study we found $36 \%$ respondents who lost their job after a disaster. After a disaster, victims require money to recover from causalities. Some of them get loan from bank and some of them don't get such facilities. In this study about $62 \%$ of the respondents affirmed that they get such type of financial support from bank or other agents where remained distributions don't get such type of facilities.

Married women are more vulnerable in the recovery initiatives organized by the government and NGOs i.e., relief distribution, sheltering etc. They became violated and discriminated when they appear at these programs. In this study majority of the respondents (about 63\%) affirmed that they faced discrimination during such occasion. In the case of married women who permanently or occasionally lack of male member, it is hard to them to get government or NGOs sponsored relief after disaster period.

\section{Recommendation and Conclusion}

Following the study results this study recommend the respective authorities:

1. Social awareness and possible responses should be increased regarding the vulnerability of married women during disaster and post-disaster period.

2. Cyclone center or any other emergency shelter center should be made in according to women friendly environment considering special privacy system for married women, separate sanitation service, special block for pregnant women along with enlisting so other facilities.

3. Government or any other NGOs relief responses should be designed based on gender characteristics and segmentation, priority and so on should be between gender biased not between gender neutrality.

4. Victim should be given extra-interest-less loan so that they can recover their lost and reform their life in according to their go.

5. Pregnant women, wounded women and women with new born child should be taken into special consideration i.e., medical care, friendly living environment and so forth.

The present study is attempted to highlight the disaster situation in Khulna district. Disaster creates unexpected events that require extra strategies either to cope with it or to reduce its impact on individual livelihood. Specially married women became more vulnerable than the male people as they are usually depended on male member as in patriarchal society male are the bread earning member. Related initiatives and sustainable measures should be taken by the respective authority as much as possible to adjust this community with the mainstream individual household.

\section{References}

[1] Islam, M. R. (2012). Vulnerability and Coping Strategies of Women in Disaster: A Study on Coastal Areas of Bangladesh. The Arts Faculty Journal, July 2010-June 2011.

[2] Nasreen, M. (2010) 'Rethinking Disaster Management: Violence against Women During Floods in Bangladesh', in Samir Dasgupta, ismail Siriner and Partha Sarathi De (ed.), Women's Encounter with Disaster, 2010, Frontpage Publications Limited, London.

[3] Nizamuddin, K. (ed.) (2001). Disaster in Bangladesh: Selected Readings, Disaster Research Training and Management Center, Department of Geography and Environment, University of Dhaka.

[4] Ali, A. (1999). Climate Change Impacts and Adaptation Assessment in Bangladesh, Climate Research, Vol. 12, Space Research and Remote Sensing Organization (SPARRSO), Dhaka.

[5] Joehnk, T. F. (2007). The great wall of India, Economist: The World in 2007, March 2007, p. 49.

[6] Barnett, J. and Adger, W. N. (2007): "Climate change, human security and violent conflict", Political Geography, 26 (6), 639-655.

[7] Paul, R. (2009). Women in Climate Change Mitigation and Adaptation, Efficient Energy Management and Renewable Energy., Dhaka, Bangladesh.

[8] Ismail, S. (2010). Gender Dimension of Economic Crises, Economic Policies and Disaster, in Women's Encounter with Disaster, eds. Dasgupta, S, Ismail Siriner, Partha Sarathi De, p 90 .

[9] Sharmin, Z. \& Islam, S. (2013). Consequences of Climate Change and Gender Vulnerability: Bangladesh Perspective. Published by Bangladesh Development Research Centre.

[10] Ahmed, A. U., Neelormi S., Adri N., Alam, M. S. \& Nuruzzaman, K. (2008). BASTOB Initiative for Peoples' SelfDevelopment, in association with Centre for Global Change (CGC); available at: http://www.bdresearch.org.bd/home/climate knowledge/cd1/p $\mathrm{df} /$ Bangladesh $\% 20$ and $\% 20$ climate $\% 20$ change/Climate $\% 20 \mathrm{ch}$ ange $\% 20$ impacts $\% 20$,vulnerability, $\% 20$ risk/CCGender VG_Jan\%2709.pdf.

[11] Rahman, S (2013). Climate Change, Disaster and Gender Vulnerability: A Study on Two Divisions of Bangladesh. American Journal of Human Ecology, Vol. 2, No. 2, 2013, 72 82. DOI: $10.11634 / 216796221302315$.

[12] Cohen, M. \& Young, P. (2007). Using micro insurance and financial education to protect and accumulate assets. In: Moser, C. (Ed.) Reducing global poverty: The case for asset accumulation. Washington, D.C.: Brookings Institution Press.

[13] Dasgupta, S., Siriner I. \& Sarathi, D. P. (editors), (2010) 'Women's encounter with disaster' Frontpage Publications Ltd, India

[14] Schiff, M. \& Sjöblom, M. (2008): Panel Data on International Migration 1975-2000, World Bank databases. 
[15] Enarson, E. (2006). Fact sheet: Women and disaster. Applied Disaster and Emergency Studies Department Brandon University, Manitoba. Available at: https://www.socwomen.org/wpcontent/uploads/2010/05/fact_10-2006-disaster.pdf

[16] Pender, S. J. (2008). "What Is Climate Change? And How It Will Affect Bangladesh", (Dhaka, Bangladesh: Church of Bangladesh Social Development Programme, Briefing Paper (Final Draft, August); available at:

http://www.kirkensnodhjelp.no/Documents/Kirkens\%20N\%C 3\%B8dhjelp/Publikasjoner/Temahefter/FINAL\%20Draft $\% 20$ WHAT\%20IS\%20CLIMATE\%20CHANGE\%20AND\%20H OW\%20IT\%20MAY\%20AFFECT\%20BANGLADESH.pdf

[17] Islam \& Sharmin. (2013). Consequences of Climate Change and Gender Vulnerability: Bangladesh Perspective. Published by Bangladesh Development Research Centre.

[18] Denton, F. \& Parikh, J. (2003). "Gender: A Forgotten Element", Tiempo, Vol. 47, pp. 27- 28; available at: http://www.tiempocyberclimate.org/portal/archive/issue47/t47 a6.htm.
[19] Joarder, R. (2013). Women in Climate Change Adaptation (CCA): A study at Sariakandi in Bogra district. Institute of Disaster Management and Vulnerability Studies University of Dhaka.

[20] GoB (Government of the People's Republic of Bangladesh), Ministry of Food and Disaster Management, Disaster Management Bureau. (2010) Standing Orders on Disaster (Dhaka, Bangladesh: GoB, Ministry of Food and Disaster Management, January); available at: http://www.dmb.gov.bd/reports/SOD_rev_30210\%20updated $\% 20$ on\%2004.02.10.pdf

[21] Household and Population Census 2011. (2011). Bangladesh Bureau of Statistics (BBS), Ministry of Planning, Government of the People's Republic of Bangladesh, Dhaka.

[22] Madge, C., Raghuram, P., Skelton, T., Willis, K., \& Williams, J. (1997). Methods and methodologies in feminist geographies: Politics, practice, power. In Women and Geography Study Group (Eds.). Feminist geographies: Explorations in diversity and difference (pp. 86-111). London: Prentice Hall. 